\title{
Redactioneel ten geleide
}

\section{C.J. in 't Veld · T. Versteegde}

Virale hepatitis is geen nieuwe ziekte, maar er is wel veel te vertellen over nieuwe ontwikkelingen in dit vakgebied die ook relevant zijn voor de huisarts. Graag nemen we $u$ mee aan de hand van de volgende bijdragen.

A. Tan, MDL-arts in het CWZ-ziekenhuis te Nijmegen, bijt het spits af met een herkenbare casus uit de dagelijkse praktijk: verhoogde leverwaarden zonder specifieke klachten. Hij legt uit waar op te letten bij anamnese en lichamelijk onderzoek, en hoe het patroon van de waarden een diagnostische clue kan zijn.

Daarna is het woord aan de collega's P. Kracht, B. van Elzen, D. Postma en A. Hoepelman, allen specialist op de afdeling Infectieziekten van het UMC Utrecht. In 'Virale hepatitis, hoe zat het ook alweer?' schetsen zij een overzicht van de transmissie en epidemiologie, het klinisch beeld en beloop, de diagnose en behandeling van de hepatotrope virussen A tot en met E.

In de volgende bijdrage besteden we aandacht aan de verbeterde diagnostische technieken. K. Grintjes-Huisman, verpleegkundig specialist en E. Tjwa, MDL-arts in het Radboud UMC in Nijmegen, beschrijven elastografie van de lever als een pijnloze, niet-invasieve manier om leverfibrose te meten. Sinds enige jaren wordt deze techniek in toenemende mate ingezet voor stadiëring van leverziekten zoals bij een hepatitis virusinfectie. Een leverbiopsie kan daarmee worden voorkomen.

Dan geeft A. Dofferhoff, infectioloog-internist van het CWZ in Nijmegen, een overzicht van de nieuwe behandelingsmethoden voor hepatitis B en C. De bijdrage is een zeer volledig overzicht en kan goed als naslagwerk dienen. De kernboodschap is duidelijk: voor hepatitis B zijn er drie orale middelen die de viral load onderdrukken en daarmee de kans op langetermijncomplicaties reduceren. Voor hepatitis $C$ is er een eenvoudige succesvolle orale therapie waarmee $95 \%$ van de patiënten in acht tot twaalf weken geneest.

C.J. in 't Veld $(\square)$

Brielle, Nederland

e-mail: c.j.intveld@gmail.com

T. Versteegde

Mook, Nederland

Bijblijven (2018) 34:517-518, https://doi.org/10.1007/s12414-018-0339-x

(C) Bohn Stafleu van Loghum is een imprint van Springer Media B.V.,

Published online: 10 September 2018 
Het succes van de hepatitis C-behandeling, samen met een verandering van de risicogroepen, heeft geleid tot beleidsmatige plannen om de ziekte te elimineren. M. van Dijk en J. Drenth, MDL-artsen in het Radboud UMC in Nijmegen, schetsen deze ontwikkelingen in een volgende bijdrage in relatie tot de rol van de huisarts hierin.

Daarna is het woord aan G. ter Beest, verpleegkundig specialist hiv en infectieziekten, Rijnstate ziekenhuis in Arnhem. Zij doet verslag van een regionaal project ter verbetering van de hepatitiszorg. Zij vertelt over de ervaringen ermee en geeft praktische tips voor wat wel en wat minder goed werkt.

Tot slot is er aandacht voor de hepatitisvaccinatie. C. van Bokhoven-Rombouts, arts infectieziektebestrijding en N. Nutma, arts maatschappij en gezondheid van de GGD Gelderland, schetsen een overzicht van de indicaties voor hepatitisvaccinatie. Het meest bekend zijn die in het kader van de reizigersadvisering naar endemische gebieden en voor medewerkers in de gezondheidszorg. Er zijn echter meer indicaties bij speciale doelgroepen en, niet minder belangrijk, wat te doen bij een uitbraak?

De redactie wenst u veel leesplezier!

C.J. in 't Veld huisarts np, Brielle.

T. Versteegde huisarts np, Mook. 